\title{
PENGARUH BUDAYA ORGANISASI DAN MOTIVASI TERHADAP KINERJA ORGANISASI PEJABAT PENGELOLA INFORMASI DAN DOKUMENTASI (PPID) PERPUSTAKAAN NASIONAL RI
}

\author{
Hartoyo Darmawan'; Soehardi²; Anton Wachidin Widjaja3 \\ Program Studi Magister Manajemen Fakultas Ekonomi Universitas Bhayangkara Jakarta \\ Raya $^{1,2,3}$ \\ hartoyo.darmawan@yahoo.com¹; soehardi@dsn.ubharajaya.ac.id²; anton.w.w@gmail.com³
}

\begin{abstract}
ABSTRAK
Penelitian ini bertujuan untuk mengetahui apakah terdapat pengaruh budaya organisasi dan motivasi terhadap kinerja organisasi Pejabat Pengelola Informasi Dokumentasi. Penelitian ini melibatkan 205 responden pegawai Perpustakaan Nasional sebagai sampel penelitian dengan metode random sampling (acak). Selanjutnya data tersebut diolah dengan menggunakan analisis regresi linier berganda. Budaya Organisasi dan Motivasi merupakan variabel independen, sedangkan Kinerja Organisasi merupakan variabel dependen. Berdasarkan hasil penelitian, analisis, dan data statistik, instrumen dalam penelitian ini bersifat valid dan reliabel. Hasil uji parsial di dapat bahwa variabel Budaya Organisasi berpengaruh positif dan signifikan terhadap Kinerja Organisasi dan variabel Motivasi juga berpengaruh terhadap Kinerja Organisasi PPID. Dan hasil uji simultan (bersamaan) variabel Budaya Organisasi dan Motivasi secara bersamasama berpengaruh positif dan signifikan. Kesimpulannya, organisasi dengan budaya yang kuat dan positif akan memungkinkan orang terasa termotivasi untuk berkembang, belajar dan memperbaiki diri. Jika orang bekerja dalam organisasi yang dikelola dengan baik akan mempunyai motivasi dan kepuasan lebih tinggi.
\end{abstract}

Kata kunci : Budaya Organisasi, Motivasi, dan Kinerja Organisasi

\author{
INFLUENCE OF ORGANIZATIONAL CULTURE AND MOTIVATION OF THE \\ PERFORMANCE OF THE INFORMATION AND DOCUMENTATION \\ MANAGEMENT OFFICERS (PPID) OF THE NATIONAL LIBRARY OF RI
}

\section{ABSTRACT}

This research aims to find out if there is influence of organization culture and motivation toward performance of Information and Documentation Management Officer organization. This research involved 205 respondents of Perpustakaan Nasional $R I$ staff as research sample with random sampling method. Data was then organized using multiple linier regression analysis. Organization Culture and Motivation are independent variables, whereas Organization Perfomance is dependent variable. Based on analysis of this research and statistic data, instrument in this research is valid and reliable. Partial test result showed that Organization Culture variable has positive and significant influence toward Organization Perfomance and Motivation variable 
also influences PPID Organization Performance. Simultaneous test result showed that Organization Culture and Motivation simultaneously have positive and significant effect. Conslucion, organizations with a strong and positive culture will enable people to feel motivated to grow, learn and improve. If people work in a well-managed organization it will have higher motivation and satisfaction.

\section{Keywords: Organization Culture, Motivation and Organization Performance}

\section{Diterima: 15 Agust 2019; Direvisi: 16 Sept 2019; Diterbitkan: 30 Okt 2019}

\section{PENDAHULUAN}

Perkembangan TIK berperan penting memudahkan Badan Publik menyampaikan informasi kepada masyarakat dan memudahkan masyarakat mengakses informasi yang diperlukan kapan saja, dimana saja. Salah satu cara mengoptimalkan pelayanan publik, yaitu dengan mengembangkan layanan situs web PPID. Situs web PPID Perpustakaan Nasional jarang mengalami pembaruan (up date) sehingga belum mendukung tugas PPID maupun pemenuhan informasi publik. Bahkan, jenisjenis informasi yang mesti disediakan setiap saat, berkala, serta merta maupun yang dikecualikan sesuai UU Keterbukaan Informasi Publik tidak nampak. Sosialisasi pemanfaatan PPID kepada lingkungan internal dan eksternal (publik) juga belum pernah dilakukan, Akibatnya, masyarakat tidak banyak yang mengetahui tugas dan fungsi dari PPID itu sendiri. Padahal, tujuan dari dibentuknya PPID adalah agar pelaksanaan pelayanan informasi publik dan hubungan masyarakat tidak tumpang tindih.

Kekhawatiran lainnya adalah belum disahkannya jenis informasi yang tidak boleh diberikan ke publik oleh Kepala Perpustakaan Nasional meski pengajuan telah lama dimintakan kepada tiap unit kerja dalam bentuk usulan. Hal ini menjadi masalah akibat belum adanya perlindungan hukum. Padahal, pada Pasal 17, UU KIP jelas mengatur bahwa setiap Badan Publik berhak menolak permohonan informasi tersebut kecuali dengan alasan yang dibenarkan oleh UU Keterbukaan Informasi Publik itu sendiri.

Di dalam pengantar buku Pedoman Pengelolaan Informasi bagi PPID (2015), disebutkan ada beragam informasi yang wajib disediakan dan diumumkan kepada publik. Pertama, informasi yang wajib disediakan dan diumumkan secara berkala (Pasal 9, UU KIP). Kedua, informasi yang wajib diumumkan secara serta merta (Pasal 10, UU KIP). Ketiga, informasi yang wajib tersedia setiap saat (Pasal 11, UU KIP). Namun, keterbukaan informasi publik tentu ada batasnya sehingga ada informasi yang dikecualikan (Pasal 17, UU KIP).

Seiring dengan hal tersebut, PPID Perpustakaan Nasional belum bekerja dengan maksimal, dikarenakan PPID belum memiliki ruang sekretariat yang representatif dengan kelengkapan sarana penunjang yang memadai, seperti seperangkat komputer, mesin fotokopi, faksimil, maupun meja pelayanan, serta tidak ada petugas yang berjaga (standby), sehingga apabila terjadi permohonan informasi, baik yang datang secara langsung atau berkirim surat atau email, akan diarahkan kepada Humas untuk menanganinya. Personil sekretariat PPID Perpustakaan Nasional yang disahkan berdasarkan SK Kepala Perpustakaan Nasional Tahun 2012 berjumlah sembilan orang, namun baru tiga orang yang memiliki keahlian di bidangnya-disebut Pejabat Fungsional Pengelola Informasi dan Dokumentasi (FPID). Sisanya, masih menjabat sebagai pengadministrasi umum karena belum 
ada lagi yang diikutsertakan bimbingan teknis (bimtek) atau pelatihan fungsional untuk PPID.

Kinerja organisasi PPID Badan Publik secara legal diawasi oleh lembaga Komisi Informasi Pusat (KIP). KIP adalah lembaga mandiri yang lahir berdasarkan Keterbukaan Informasi Publik (UU KIP). Perpustakaan Nasional RI merupakan salah satu dari Lembaga Pemerintah Non Kementerian (LPNK) yang rmasuk ke dalam penilaian dari KIP. Lembaga KIP bertanggung jawab langsung kepada Presiden RI. Pada beberapa kesempatan, misalnya, KIP tanpa memberitahu Badan Publik akan memantau dan berpura-pura layaknya pemohon informasi untuk secara langsung melihat kesiapan petugas PPID, serta alat bantu yang digunakan dalam menerima pemohon informasi.

Sebelumnya, pada Mei 2016, Komisi Informasi Pusat memintakan kepada setiap Badan Publik LN/LPNK mengisi kuesioner penilaian mandiri (Self Assessment Questionnaire-SAQ). SAQ secara garis besar berisikan informasi yang berkaitan dengan profil lembaga, kegiatan (kinerja), keuangan, laporan akses informasi, laporan tata cara permohonan informasi, laporan tata acara pengaduan penyalahgunaan/ pelanggaran, pengadaan barang dan jasa, regulasi-regulasi (peraturan), daftar informasi publik, peraturan/keputusan dan atau kebijakan suratsurat perjanjian dengan pihak ke-tiga, organisasi, administrasi, kepegawaian, pedoman pelayanan publik, dan laporan pelayanan informasi publik Badan Publik.

Pada tanggal 11 Juli 2016, Komisi Informasi Pusat dengan Nomor Surat : 39/KIP/J.II/VII/2016, melayangkan Surat Hasil Pra Evaluasi Monitoring dan Evaluasi Pemeringkatan Badan Publik dalam Penerapan Keterbukaan Informasi Publik Tahun 2016. Hasil tersebut dijadikan tolak ukur penilaian yang menghasilkan peringkat Keterbukaan Informasi Publik dan dilaporkan kepada Presiden RI. Hasil SAQ yang diterima Perpusnas menurut verifikasi Komisi Informasi Pusat memperoleh penilaian 29,51282051. Penilaian tersebut menghasilkan beberapa catatan penting yang diperoleh Perpustakaan Nasional berdasarkan pemeriksaan SAQ tersebut. Khusus di bidang informasi, Komisi Informasi Pusat memberikan catatan, antara lain :

1. Penyediaan informasi yang termuat dalam Daftar Informasi Publik dan pelayanan informasi publik masih sangat perlu ditingkatkan;

2. Laporan akses informasi publik ke KIP, formulir dan tanda terima permohonan serta daftar register permohonan juga perlu ditingkatkan, serta

3. Perlu ditingkatkan pola koordinasi PPID dan penunjukkannya serta tugas dan tanggung jawab.

Minimnya sosialisasi internal dan belum adanya sosialisasi secara eksternal tentang apa itu PPID akibat dari cara pandang pejabat PPID yang masih menganggap PPID belum penting diterapkan. Para pejabat PPID masih bersikap konservatif terhadap perubahan, terlalu fokus pada kondisi internal, belum siap mengikuti perkembangan budaya dan arus teknologi informasi komunikasi (TIK) yang dinamis. Budaya adalah fenomena yang dinamis. Namun, seperti diketahui kebanyakan orang sangat anti dengan perubahan (people do not like to change). Para pejabat PPID Perpustakaan Nasional masih terlalu fokus dengan rutinitas pekerjaan strukturalnya mengingat organisasi PPID bukan menjadi bagian dari struktural kelembagan Perpustakaan Nasional. Mekanisme pelayanan informasi publik lebih banyak ditangani oleh desk pelayanan dan informasi perpustakaan dan Sub Bagian Humas.

Perilaku sumber daya manusia memegang peranan penting dalam organisasi bagi keberhasilan organisasi. Artinya, kinerja organisasi akan dapat meningkat melalui perbaikan pada perilaku sumber daya manusianya. Sebaliknya, kelesuan kinerja organisasi lama-kelamaan bisa mengikis kinerja organisasi itu sendiri, dan menipiskan motivasi kinerja personil yang berada dalam lingkup organisasi tersebut. Motivasi diartikan sebagai seperangkat kekuatan (energi) yang 
berasal dari dalam dan luar, menentukan tujuan, intensitas serta kegigihannya.

Keberadaan PPID Perpustakaan
Nasional baru sebatas menggugurkan
kewajiban melaksanakan amanah UU KIP
sehingga belum terlihat upaya pengoptimalan
dari kinerja PPID Perpustakaan Nasional. Oleh
sebab itu, peranan budaya organisasi dan
motivasi amatlah penting dalam meningkatkan
kinerja organisasi (organization performance)
PPID di Perpustakaan Nasional, karena dengan
pelayanan PPID yang optimal, penilaian
kinerja pelayanan publik PPID Perpustakaan
Nasional yang dilakukan oleh lembaga KIP
akan semakin baik yang berimplikasi citra
positif bagi instansi Perpustakaan Nasional di
mata masyarakat.

\section{KAJIAN TEORETIK}

\section{Budaya Organisasi}

Budaya organisasi merupakan sistem penyebaran kepercayaan dan nilai-nilai yang berkembang dalam suatu organisasi dan mengarahkan perilaku anggota-anggotanya. Budaya organisasi adalah perekat sosial yang mengikat anggota dan organisasi. Budaya yang kuat akan mendukung organisasi dalam mencapai tujuan organisasi.

Konsep budaya organisasi baru berkembang sekitar awal 1980-an. Konsep ini diakui oleh para teoritisi organisasi diadopsi dari konsep budaya yang terlebih dulu berkembang pada ilmu antropologi. Menurut Vijai Sathe dalam Sobirin (2007, p.129) secara umum, konsep budaya organisasi dibagi menjadi dua, ideational dan adaptionist school. Ideational school melihat budaya sebuah organisasi dari apa yang di-shared (dipahami, dijiwai, dan dipraktekkan bersama). Sedangkan adaptionist school melihat budaya dari kulit luar organisasi. Memperlakukan budaya sebagai variabel internal untuk meningkatkan efektivitas organisasi.
Menurut Jason A. Colquitt (2015:99). Organizational culture the shared social knowledge within an organization regarding the rules,norms, and values that shape the attitudes and behaviors of its employees. Artinya Budaya organisasi merupakan pengetahuan sosial bersama dalam sebuah organisasi mengenai peraturan, norma, dan nilai yang membentuk sikap dan perilaku karyawannya. Sedangkan menurut Certo (2016:99), Organization culture is a set of values that organization members share regarding the functioning and existence of their organization. Artinya budaya organisasi adalah seperangkat nilai yang dimiliki anggota organisasi mengenai fungsi dan keberadaan organisasinya.

Menurut Ricky.W.Griffin (2016:99), Organizational culture is the set of values, beliefs, behaviors, customs, and attitudes that helps the organization's members understand what it stands for, how it does things, and what it considers important. Artinya budaya organisasi adalah seperangkat nilai, kepercayaan, perilaku, kebiasaan, dan sikap yang membantu anggota organisasi memahami apa yang menjadi tujuannya, bagaimana hal itu melakukan sesuatu, dan apa yang dianggap penting.

Menurut Stephen P. Robbins (2016:99), Organizational culture the shared values, principles, traditions, and ways of doing things that influence the way organizational members act and that distinguish the organization from other organizations. Artinya budaya organisasi adalah nilai, prinsip, tradisi, dan cara berbagi dengan cara yang mempengaruhi cara kerja anggota organisasi dan yang membedakan organisasi dari organisasi lain. Sedangkan, Michael Amstrong (2009:384) mengatakan "organization culture is the pattern of values, norms, beliefs, attitudes, and assumption that may not have been articulated but that shape the ways in which people in organization behave and things get done" - Budaya organisasi 
merupakan pola nilai, norma, kepercayaan, sikap dan anggapan yang mungkin belum diartikulasikan tetapi membentuk cara dimana orang dalam organisasi berperilaku dan menyelesaikan pekerjaan.

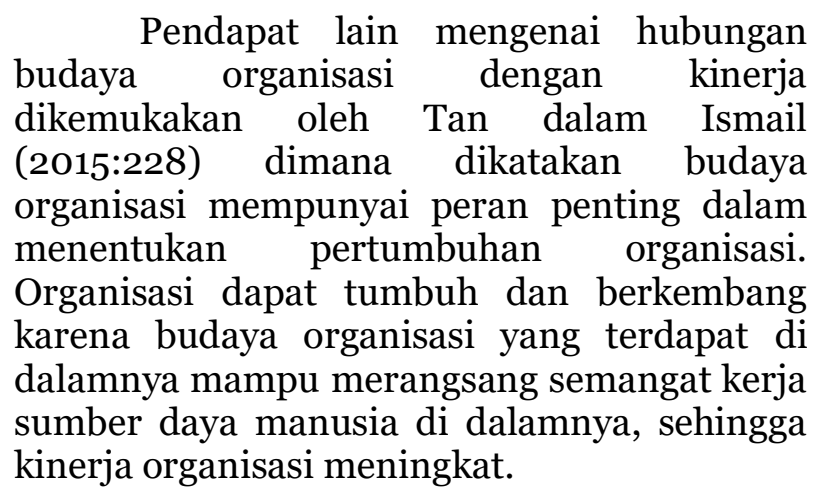

Andrew J Dubrin (2012, p.288) mengatakan, the dimensions of organizational culture help explain the subtle forces that influence employee actions-Dimensi budaya organisasi membantu menjelaskan kekuatan yang mempengaruhi tindakan karyawan. Adapun budaya organisasi menurut Hofstede dalam Sobirin (2007, p.187) dibagi ke dalam beberapa dimensi, antara lain :

\section{Process oriented vs Result Oriented}

Pada process oriented culture, perhatian organisasi lebih ditujukan pada proses aktivitas yang berjalan selama ini dan sejauh mana orang-orang yang bekerja pada organisasi tersebut patuh terhadap ketentuan-ketentuan atau kebijakan yang telah digariskan organisasi. Akibat dari orientasi tersebut, secara behavioral, menyebabkan orang-orang yang bekerja di dalam organisasi tidak antusias dalam pekerjaannya dan menganggap kehidupan sehari-hari di dalam organisasi hanyalah sebuah rutinitas belaka. Kreativitas dan inovasi tampaknya sulit dikembangkan kecuali mereka ditunjukkan bahwa organisasi lain telah melakukannya. Sementara, pada result oriented culture, perhatian organisasi lebih ditujukan pada hasil kegiatan ketimbang prosesnya sehingga seringkali organisasi tidak mempedulikan bagaimana proses dilakukan tetapi yang penting hasilnya cepat didapat.
Akibat lainnya, adalah boleh jadi perubahan proses menjadi hal biasa jika dianggap proses berjalan tidak segera mendatangkan hasil.

2. Open System vs Closed System Culture Open system culture menjelaskan bahwa organisasi cenderung tidak menutup diri dari perubahan-perubahan baik yang terjadi pada lingkungan internal maupun eksternal organisasi. Orang-orangnya lebih terbuka dan responsif terhadap usulan perubahan organisasi ; lebih terbuka pada pendatang baru dan orang luar. Bisa dikatakan bahwa setiap orang hanya butuh waktu yang relatif singkat untuk merasa cocok dengan kondisi organisasi. Pun, dengan pendatang baru, tidak butuh waktu lama untuk merasa at home.

3. Loose Control Culture vs Tight Control Culture

Pada organisasi dengan tingkat pengendalian yang longgar (loose control), organisasi seolah-olah tidak memiliki alat kendali dan tata aturan formal yang memungkinkan organisasi tersebut bisa mengendalikan orang-orang yang bekerja di dalamnya. Semuanya dikendalikan dengan aturan yang serba longgar. Akibatnya, secara operasional, setiap orang hampir tidak ada yang peduli dengan biaya, target waktu hampir tidak terpenuhi dan sebagian orang bekerja dengan santai.

Kebalikannya, tight control culture, cenderung menerapkan aturan-aturan yang ketat dan bahkan dalam batas-batas tertentu cenderung kaku. Jika organisasi loose control culture bisa dianalogikan dengan organisasi yang menggunakan pendekatan human relation approach, maka tight control culture dianalogikan dengan scientific management approach.

\section{Motivasi}

Sumber daya manusia merupakan salah satu unsur yang sangat menentukan keberhasilan suatu organisasi dalam mencapai tujuannya. Untuk mencapai tujuan organisasi, maka salah satu yang perlu dilakukan pimpinan 
adalah memberikan daya dorong agar karyawan bekerja sesuai dengan yang diinginkan organisasi. Daya dorong tersebut disebut dengan motivasi. Motivasi adalah pendorong utama seseorang dalam melakukan pekerjaan. Seseorang yang memiliki motivasi tinggi akan lebih giat bekerja, sebaliknya yang rendah motivasinya akan menampakkan semangat kerja yang kurang. Seorang pekerja menjadi kreatif atau tidak kreatif, rajin atau tidak rajin bisa ditelusuri dari motivasinya.

Chuck William (2011, p. 491) mengatakan "motivation is the set of forces that initiates, direct, and makes people persit in their efforts to accomplish a goal" - Motivasi merupakan seperangkat daya yang memulai, mengarahkan, dan membuat orang gigih dalam usahanya mencapai tujuan. Sedangkan, Michael Amstrong (2009, p.317) menyebutkan "motivation is concerned with the strength and directions of behavior and the factors that influence people to behave in certain ways. Motivation can be described as goal director behaviour"-Motivasi berkaitan dengan kekuatan, dan arah perilaku dan faktor yang mempengaruhi orang untuk berperilaku sedemikian rupa. Motivasi dapat digambarkan sebagai tujuan perilaku.

Michael Amstrong (2009, p.89) mengatakan ada sepuluh cara motivasi manusia (10 ways of motivating people), antara lain :

1. Agree demanding but achievable goals (menyetujui tujuan yang menuntut tujuan tersebut dapat dicapai)

2. Create expectations that certain behaviours and outputs will produce worthwhile rewards when people succed (menciptakan harapan yang mana perilaku dan output tertentu akan menghasilkan penghargaan yang sepadan saat seseorang sukses) $a$.

3. Provide feedback on performance (memberikan umpan balik tentang kinerja)

4. Design job that enable people to feel a sense of accomplishment, to express and use their abilities, and to exercise their own decision- making powers (merancang pekerjaan yang memungkinkan seseorang untuk merasakan perasaan berprestasi, mengungkapkan dan menggunakan kemampuan mereka, dan melatih kemampuan membuat keputusan sendiri)

5. Make good use of the organizations reward system to provide appropriate financial incentives (memanfaatkan sistem penghargaan organisasi untuk menyediakan keuangan yang layak)

6. Provide recognition and praise for work well done (memberikan pengakuan dan pujian untuk pekerjaan yang dikerjakan dengan baik)

7. Communicate to your team and it's members the link between performance and reward, thus enhancing expectations (mengkomunikasikan pada kelompok dan anggota tentang hubungan antara kinerja dan penghargaan sehingga meningkatkan harapan)

8. Provide effective leadership (menetapkan kepemimpinan yang efektif)

9. Give people the guidance and training that will develop the knowledge and skills they need to improve their performance and be rewarded accordingly (memberikan orang panduan dan pelatihan yang akan mengembangkan pengetahuan keterampilan yang mereka butuhkan untuk memperbaiki kinerja mereka dan dihargai dengan layak)

10. Offer opportunities for learning and development that will enable them to advance their careers (menawarkan kesempatan untuk pembelajaran dan pengembangan yang akan memungkinkan mereka untuk memajukan karirnya)

Herzberg mengemukakan teori motivasinya yang bertumpu pada sisi kajian :

\section{Motivasi factors}

Faktor ini mempengaruhi tingkat kepuasan bekerja berdasarkan pemenuhan kebutuhan tingkat tinggi seperti pencapaian, tanggung jawab, penghargaan, dan peluang untuk bertumbuh. Yang 
tergolong faktor motivasional, antara lain pekerjaan, kemajuan karir, keberhasilan yang diraih, dan pengakuan dari orang lain.

2. Hygiene factors

Hygiene factors melihat bagaimana lingkungan kerja, dan kondisi kerja mempengaruhi dorongan seseorang sehingga memiliki motivasi kuat dalam membangun semangat kerja.

Dari berbagai pendapat tersebut, dapat disimpulkan bahwa motivasi adalah dorongan untuk bertindak terhadap serangkaian proses perilaku manusia dengan mempertimbangkan arah, ketekunan, intensitas pada tujuan yang mau dicapai. Elemen yang terkandung dalam motivasi meliputi unsur membangkitkan, menjaga, mengarahkan, menunjukkan intensitas dan bersifat kontinyu serta adanya tujuan yang jelas.

Menurut Newstrom dalam Wibowo (2015, p. 110) mengemukakan indikatorindikator motivasi, antara lain :

1. Engagement

Merupakan janji pekerja untuk

menunjukkan tingkat antusiasme, inisiatif, dan usaha untuk meneruskan.

2. Commitment

Adalah suatu tingkatan dimana pekerja mengikat dengan organisasi dan menunjukkan tindakan organizational citizenship

3. Satisfaction

Kepuasan merupakan refleksi pemenuhan kontrak psikologis dan memenuhi harapan di tempat kerja

\section{Kinerja Organisasi}

Kinerja dalam suatu organisasi dilakukan oleh segenap sumber daya manusia dalam organisasi, baik unsur pimpinan maupun pekerja. Kinerja dapat dipandang sebagai proses maupun hasil pekerjaan. Kinerja merupakan suatu proses tentang bagaimana pekerjaan berlangsung untuk mencapai hasil kerja. Namun, hasil pekerjaan itu sendiri juga menunjukkan kinerja. Kinerja organisasi tidak hanya dipengaruhi sumber daya manusia di dalamnya, tapi juga oleh sumber daya lainnya seperti dana, bahan, peralatan, teknologi, dan mekanisme yang berlangsung di dalam organisasi.

Menurut ALDamoe et al (2012:99) Organization performance is measured through financial and non-financial measures like sale, profit, and market share and nonfinancial factors measures are efficiency, quality of service, productivity of organization, satisfaction of employees and commitment these factors can increase through training. Kinerja organisasi diukur melalui langkah-langkah finansial dan nonkeuangan seperti ukuran penjualan, keuntungan, dan pangsa pasar dan faktor nonkeuangan adalah efisiensi, kualitas layanan, produktivitas organisasi, kepuasan karyawan dan komitmen faktor-faktor ini dapat meningkat melalui pelatihan.

Menurut Mahapatro (2010:99) Organizational performance as the ability of anorganization to fulfill its mission through sound management, strong governance and a persistent rededication to achieving results. Artinya kinerja organisasi sebagai kemampuan sebuah organisasi untuk memenuhi misinya melalui manajemen yang baik, tata pemerintahan yang kuat dan dedikasi yang gigih untuk mencapai hasil.

Kinerja menurut Mahmudi (2007, p. 20) merupakan suatu konstruk multidimensional yang mencakup banyak faktor yang mempengaruhinya. Faktor-faktor yang mempengaruhinya, antara lain :

1. Faktor personal/individu, meliputi pengetahuan, keterampilan (skill), kemampuan, kepercayaan diri, motivasi, dan komitmen yang dimiliki oleh setiap orang

2. Faktor kepemimpinan, meliputi kualitas dalam memberi dorongan, semangat, arahan dan dukungan yang diberikan manajer dan team leader

2. Faktor tim, meliputi kualitas dukungan dan semangat yang diberikan oleh rekan dalam satu tim, kepercayaan terhadap anggota tim, kekompakan dan keeratan anggota tim 
3. Faktor sistem, meliputi sistem kerja, fasilitas kerja, atau infrastruktur yang diberikan oleh organisasi, proses organisasi, dan kultur kinerja dalam organisasi

4. Faktor kontekstual (situasional), meliputi tekanan dan perubahan lingkungan eksternal dan internal.

Menurut Mahmudi (2007, p 89) penentuan indikator kinerja memerlukan pertimbangan komponen sebagai berikut :

1. Kualitas dan standar pelayanan (quality and standards). Penentuan indikator kinerja juga harus mencakup indikator yang sifatnya kualitatif, misalnya kualitas pelayanan dan standar pelayanan. Indikator kualitas pelayanan, contohnya kecepatan pelayanan, ketepatan waktu, keramahan, kenyamanan, kecepatan respon, keamanan, kebersihan, etika. Sedangkan standar pelayanan mencakup pada tingkat pelayanan minimal yang harus diberikan.

2. Kepuasan pelanggan (citizen's satisfaction) Pelanggan adalah tamu yang harus dihormati. Jika hendak dispesifikan, terdapat dua pelanggan, yakni internal dan eksternal. Pelanggan internal adalah orang yang bagian lain dalam organisasi yang menggunakan output dari itu. Sedangkan, pelanggan eksternal adalah pihak di luar organisasi yang memakai atau memanfaatkan keluaran yang dihasilkan organisasi. Adanya ketidaksesuaian antara outcome yang dihasilkan dari suatu pelayanan dengan kepuasan masyarakat menunjukkan masih adanya kesenjangan harapan (expectation gap)

Sedangkan menurut Wibowo (2016, p. 88) kompetensi juga menjadi bagian dari indikator kinerja. Kompetensi merupakan kemampuan yang dimiliki seseorang untuk menjalankan pekerjaan yang diberikan kepadanya dengan baik. Lebih dari sekedar belajar tentang sesuatu, tapi juga harus melakukannya dengan baik. Kompetensi memungkinkan seseorang melakukan tugas yang berkaitan dengan pekerjaan yang diperlukan untuk mencapai tujuan.

\section{Pejabat Pengelola Informasi dan Dokumentasi (PPID)}

PPID adalah badan informasi publik yang merupakan turunan dari KIP. PPID dibentuk khusus mengelola dan memberi pelayanan informasi yang dibuat secara sederhana, efisien, dan ramping. Tidak melalui jenjang birokrasi yang berbelit-belit dan memakan waktu lama. UU KIP tidak spesifik apakah badan informasi publik didirikan tersendiri atau menjadi bagian dari bidang tertentu, seperti Humas.

Namun, keduanya memiliki tugas dan fungsi yang berbeda. Paradigma Humas menurut Buku Panduan KIP (2009, p. 49) adalah mengontrol informasi yang akan disampaikan dan membentuk citra yang diinginkan. Sedangkan paradigma pelayanan informasi publik adalah maximum acces limited exemption (MALE), yakni memberikan informasi sebanyak-banyaknya dengan pengecualian yang terbatas. Bidang pelayanan informasi publik tidak dapat mengontrol permohonan informasi yang datang dan mesti melayani semua permohonan informasi sepanjang bukan informasi yang dikecualikan.

Badan Informasi Publik (PPID) memiliki fungsi, antara lain :

1. Mengumpulkan data dan informasi pada lembaga

2. Mengelola informasi publik

3. Mengkategorikan informasi

4. Membangun database informasi

5. Menerima permintaan informasi

6. Mengirim informasi kepada pemohon

Pengelolaan informasi dan dokumentasi di Perpustakaan Nasional Republik Indonesia (Perpusnas) dibentuk berdasarkan Surat Keputusan (SK) Kepala Perpustakaan Nasional Nomor 20 Tahun 2012 tentang Pembentukan Organisasi Pengelola Informasi dan Dokumentasi. Lalu diperkuat melalui SK Kepala Perpustakaan Nomor 126 Tahun 2013 tentang Organisasi Pengelola 
Informasi dan Dokumentasi Perpustakaan Nasional yang menjadi landasan hukum dibentuknya PPID di Perpusnas.

\section{Kerangka Berpikir dan Hipotesis}

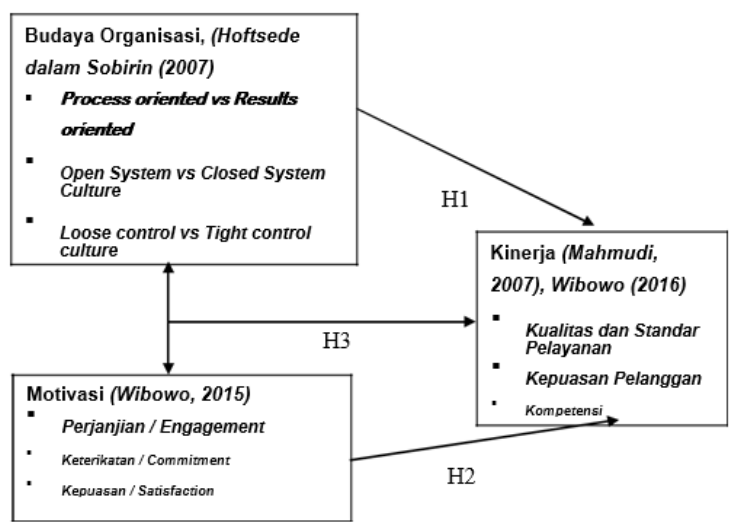

Gambar 1.

Kerangka Berpikir

\section{Metode Penelitian}

Metode penelitian dalam penelitian ini adalah metode penelitian kuantitatif dengan analisis uji t, $\mathrm{F}$ dan multiple linear regression. Teknik pengumpulan data yang digunakan dalam penelitian ini adalah dengan metode survei. Pengumpulan data dilakukan dengan menggunakan kuesioner. Penarikan sampel dilakukan secara acak (simple random sampling). Dikatakan simpel karena pengambilan sampel dari populasi dilakukan secara acak tanpa strata yang ada dalam populasi itu sejumlah 415. Untuk mendapatkan sampel yang menggambarkan populasi, maka dalam penelitian ini digunakan Rumus Slovin didapat 205 .

Teknik sampling dalam penelitian ini menggunakan teknik random sampling. Populasi dan sample yang digunakan dalam penelitian ini adalah sebanyak 300 kemudian di beri kuesioner yang kembalikan sebanyak 267, namun yang dapat digunakanl dalam penelitian ini hanya sebanyak 225 sampling.

\section{HASIL PENELITIAN DAN PEMBAHASAN}

Tabel 1.

Uji Validitasi Budaya Organisasi (X1)

\begin{tabular}{|c|c|r|c|}
\hline $\begin{array}{c}\text { Pernyataan Variabel Budaya } \\
\text { Organisasi (X1) }\end{array}$ & R hitung & Kkntts & Kesmmpulan \\
\hline Pernyataan 1 & $0,527^{* *}$ & 0,444 & Valid \\
\hline Pernyataan 2 & $0,466^{* *}$ & 0,444 & Valid \\
\hline Pernyataan 3 & $0,738^{* *}$ & 0,444 & Valid \\
\hline Pernyataan 4 & $0,554^{* *}$ & 0,444 & Valid \\
\hline Pernyataan 5 & $0,629^{* *}$ & 0,444 & Valid \\
\hline Pernyataan 6 & $0,510^{* *}$ & 0,444 & Valid \\
\hline Pernyataan 7 & $0,528^{* *}$ & 0,444 & Valid \\
\hline Pernyataan 8 & $0,718^{* *}$ & 0,444 & Valid \\
\hline Pernyataan 9 & $0,541^{* *}$ & 0,444 & Valid \\
\hline Pernyataan 10 & $0,579^{* *}$ & 0,444 & Valid \\
\hline Pernyataan 11 & $0,726^{* *}$ & 0,444 & Valid \\
\hline Pernyataan 12 & $0,591^{* *}$ & 0,444 & Valid \\
\hline Pernyataan 13 & $-0,376^{* *}$ & 0,444 & Tidak Valid \\
\hline Pernyataan 14 & $0,268^{* *}$ & 0,444 & Tidak Valid \\
\hline Pernyataan 15 & $0,475^{* *}$ & 0,444 & Valid \\
\hline Pernyataan 16 & $0,630^{* *}$ & 0,444 & Valid \\
\hline Pernyataan 17 & $0,690^{* *}$ & 0,444 & Valid \\
\hline Pernyataan 18 & $0,634^{* *}$ & 0,444 & Valid \\
\hline Pernyataan 19 & $0,633^{* *}$ & 0,444 & Valid \\
\hline Pernyataan 20 & $0,738^{* *}$ & 0,444 & Valid \\
\hline
\end{tabular}

Sumber: Data SPSS Ve. 22.0 yang diolah, 2017

Tabel 2.

Uji Validitasi Motivasi (X2)

\begin{tabular}{|c|c|c|c|}
\hline $\begin{array}{c}\text { Pernyataan Variabel Motivasi } \\
\text { (X2) }\end{array}$ & R hitung & Rkritis & Kesimpulan \\
\hline Pernyataan 1 & $0,530^{* *}$ & 0,444 & Valid \\
\hline Pernyataan 2 & $0,845^{* *}$ & 0,444 & Valid \\
\hline Pernyataan 3 & $0,852^{* *}$ & 0,444 & Valid \\
\hline Pernyataan 4 & $0,836^{* *}$ & 0,444 & Valid \\
\hline Pernyataan 5 & $0,100^{* *}$ & 0,444 & Tidak Valid \\
\hline Pernyataan 6 & $0,741^{* *}$ & 0,444 & Valid \\
\hline Pernyataan 7 & $0,868^{* *}$ & 0,444 & Valid \\
\hline Pernyataan 8 & $0,623^{* *}$ & 0,444 & Valid \\
\hline Pernyataan 9 & $0,789^{* *}$ & 0,444 & Valid \\
\hline Pernyataan 10 & $0,818^{* *}$ & 0,444 & Valid \\
\hline Pernyataan 11 & $0,719^{* *}$ & 0,444 & Valid \\
\hline Pernyataan 12 & $0,741^{* *}$ & 0,444 & Valid \\
\hline Pernyataan 13 & $0,525^{* *}$ & 0,444 & Valid \\
\hline Pernyataan 14 & $0,703^{* *}$ & 0,444 & Valid \\
\hline Pernyataan 15 & $0,362^{* *}$ & 0,444 & Tidak Valid \\
\hline Pernyataan 16 & $0,688^{* *}$ & 0,444 & Valid \\
\hline Pernyataan 17 & $0,868^{* *}$ & 0,444 & Valid \\
\hline Pernyataan 18 & $0,609^{* *}$ & 0,444 & Valid \\
\hline Pernyataan 19 & $0,589^{* *}$ & 0,444 & Valid \\
\hline Pernyataan 20 & $0,741^{* *}$ & 0,444 & Valid \\
\hline
\end{tabular}

Sumber : Data SPSS Ve. 22.0 yang diolah, 2017 
Tabel 3 .

Uji Validitasi Kinerja (Y)

\begin{tabular}{|c|c|c|c|}
\hline $\begin{array}{c}\text { Pernyataan Variabel Kinerja } \\
\text { Organisasi (Y) }\end{array}$ & R hitung & Rkritis & Kesimpulan \\
\hline Pernyataan 1 & $0,684^{* *}$ & 0,444 & Valid \\
\hline Pernyataan 2 & $0,591^{* *}$ & 0,444 & Valid \\
\hline Pernyataan 3 & $0,724^{* *}$ & 0,444 & Valid \\
\hline Pernyataan 4 & $0,595^{* *}$ & 0,444 & Valid \\
\hline Pernyataan 5 & $0,464^{* *}$ & 0,444 & Valid \\
\hline Pertanyaan 6 & $0,673^{* *}$ & 0,444 & Valid \\
\hline Pernyataan 7 & $0,793^{* *}$ & 0,444 & Valid \\
\hline Pernyataan 8 & $0,617^{* *}$ & 0,444 & Valid \\
\hline Pernyataan 9 & $0,787^{* *}$ & 0,444 & Valid \\
\hline Pernyataan 10 & $0,599^{* *}$ & 0,444 & Valid \\
\hline Pernyatan 11 & $0,616^{* *}$ & 0,444 & Valid \\
\hline Pernyataan 12 & $0,660^{* *}$ & 0,444 & Valid \\
\hline Pernyataan 13 & $0,511^{* *}$ & 0,444 & Valid \\
\hline Pernyataan 14 & $0,141^{* *}$ & 0,444 & Tidak Valid \\
\hline Pernyataan 15 & $0,647^{* *}$ & 0,444 & Valid \\
\hline Pernyataan 16 & $0,284^{* *}$ & 0,444 & Tidak Valid \\
\hline Pernyatan 17 & $0,704^{* *}$ & 0,444 & Valid \\
\hline Pernyataan 18 & $0,724^{* *}$ & 0,444 & Valid \\
\hline Pernyataan 19 & $0,651^{* *}$ & 0,444 & Valid \\
\hline Pernyataan 20 & $0,665^{* *}$ & 0,444 & Valid \\
\hline Sumber : Data SPSS Ve. 22.0 yang diolah, 2017 & &
\end{tabular}

Tabel 4.

Uji Reliabilitas

\begin{tabular}{|c|c|c|}
\hline Variabel & Cronbach's Alpha & Keterangan \\
\hline Budaya Organisasi (X1) & 0,852 & Realibel \\
\hline Motivasi (X2) & 0,927 & Realibel \\
\hline Kinerja Organisasi (Y) & 0,921 & Realibel \\
\hline Sumber : Data yang diolah, 2017
\end{tabular}

Berdasarkan hasil uji normalitas dengan Kolmogorov Smirnov, data histogram dan data P-Plot diketahui bahwa masingmasing variabel dapat disimpulkan berdistribusi normal.

Tabel 5 .

Uji t

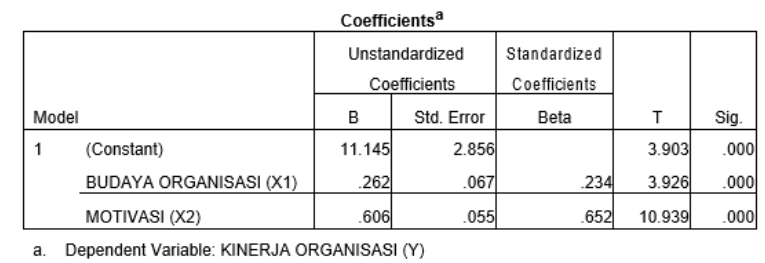

Berdasarkan hasil uji t pada variabel X1, diketahui bahwa $t$ hitung $(3,926)>t$ tabel $(1,658)$ dan nilai signifikansi $0,000<0,05$, maka dapat dikatakan ada pengaruh budaya organisasi terhadap kinerja karyawan. Begitu pula dengan hasil uji $\mathrm{t}$ pada variabel $\mathrm{X} 2$, diketahui bahwa $t$ hitung $(10,939)>t$ tabel $(1,658)$ dan nilai signifikansi $0,000<0,05$, maka dapat dikatakan ada pengaruh motivasi terhadap kinerja karyawan.

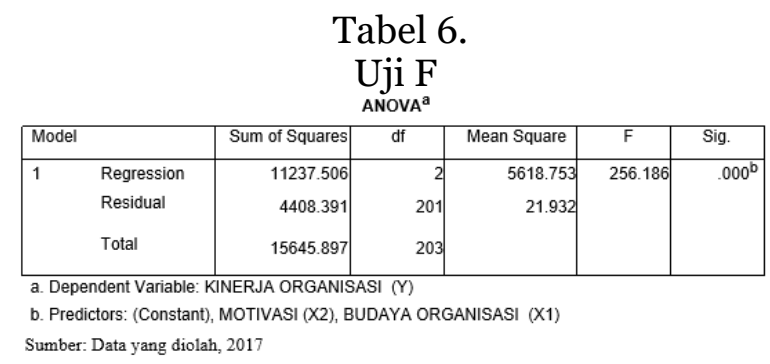

Berdasarkan hasil uji $\mathrm{F}$, diketahui bahwa F hitung $(256,186)>\mathrm{t}$ tabel $(6,85)$ dan nilai signifikansi $0,000<0,05$, maka dapat dikatakan ada pengaruh budaya organisasi dan motivasi terhadap kinerja karyawan.

Model persamaan regresi linier ganda hasil penelitian adalah $\hat{Y}=11,145+0,262 X 1+$ o,606 X2. Model persamaan regresi linier ganda hasil analisis tersebut dapat diartikan sebagai berikut:

a. Nilai konstanta sebesar a $=11,145$, artinya bahwa jika budaya organisasi dan motivasi positif maka kinerj akaryawan akan bernilai positif.

b. Nilai koefisien regresi budaya organisasi sebesar b1 = 0, 262 menunjukkan bahwa budaya organisasi berpengaruh terhadap kinerja kerja dengan arah positif, artinya semakin baik budaya organisasi maka semakin tinggi kinerja kerja.

c. Nilai koefisien regresi motivasi sebesar b2 = o,606 menunjukkan bahwa motivasi berpengaruh terhadap kinerja kerja dengan arah positif, artinya semakin baik motivasi maka semakin tinggi kinerja kerja. 
Tabel 7.

Model Summary Pengaruh Budaya Organisasi dan Motivasi Terhadap Kinerja

Koefisien Determinan ( )

Model Summary

\begin{tabular}{|l|c|r|r|r|r|}
\hline Model & $\mathrm{R}$ & $\mathrm{R}$ Square & \multicolumn{1}{c|}{$\begin{array}{c}\text { Adjusted R } \\
\text { Square }\end{array}$} & $\begin{array}{c}\text { Std. Error of the } \\
\text { Estimate }\end{array}$ & Durbin-Watson \\
\hline 1 & $.847^{\mathrm{a}}$ & .718 & .715 & 4.683 & 1.453 \\
\hline
\end{tabular}

a. Predictors: (Constant), MOTIVASI (X2), BUDAYA ORGANISASI (X1)

b. Dependent Variable: KINERJA ORGANISASI $(Y)$

Sumber: Data yang diolah, 2017

Dari tabel tersebut diatas diperoleh nilai koefisien determinasi ganda yang disesuaikan (Adjusted R Square) sebesar 0.715. Nilai Adj. R ${ }^{2}$ $=0.715$ menunjukkan bahwa budaya organisasi dan motivasi dalam model secara bersamasama mampu menjelaskan $71,5 \%$ variasi $\mathrm{Y}$ sedangkan $28,5 \%$ variasi Y lainnya dijelaskan oleh variabel lain yang tidak diteliti.

\section{Pengaruh Budaya Organisasi terhadap Kinerja Organisasi (Y)}

(X1)

Berdasarkan hasil perhitungan, diperoleh angka t penelitian sebesar 3,926 $>t$ tabel sebesar 1,971 artinya ada pengaruh secara parsial antara Budaya Organisasi (X1) dengan Kinerja Organisasi $(\mathrm{Y})$. Sedangkan dilihat dari nilai signifikannya 0,00o lebih kecil dari 0,05 bahwa Budaya Organisasi (X1) berpengaruh positif signifikan terhadap Kinerja Organisasi (Y). Budaya Organisasi adalah cara orang melakukan sesuatu dalam organisasi. Merupakan satuan norma yang terdiri dari keyakinan, sikap, core values, dan pola perilaku yang dilakukan orang dalam organisasi. Budaya organisasi yang kuat tentu akan mendukung tujuan-tujuan dari perusahaan/instansi. Sebaliknya, yang lemah atau negatif akan menghambat atau bertentangan dengan tujuan-tujuan perusahaan/instansi. Organisasi dengan budaya yang kuat dan positif akan memungkinkan orang terasa termotivasi untuk berkembang, belajar dan memperbaiki diri. Jika orang bekerja dalam organisasi yang dikelola dengan baik akan mempunyai motivasi dan kepuasan lebih tinggi.

Hasil penelitian ini mendukung penelitian terdahulu yang dilakukan oleh Yonavia Latuny (2010), "Pengaruh Budaya
Organisasi Dan Motivasi Terhadap Kinerja Karyawan PADA PT. Allianz Life Indonesia DI Denpasar". Responden dalam penelitian ini dilakukan dengan mengambil sample sebanyak 112 orang, data yang dikumpulkan dengan menggunakan kuesioner yang berupa daftar pertanyaan, teknik analisis. Data yang dipergunakan adalah analisis regresi berganda dengan menggunakan program SPSS 15.O For Windows. Sedangkan variabel secara parsial ada pengaruh yang signifikan terhadap kinerja karyawan pada PT. Allianz Life Indonesia.

\section{Pengaruh variabel Motivasi terhadap Kinerja Organisasi (Y)}

(X2)

Berdasarkan hasil perhitungan, diperoleh angka t penelitian sebesar 10,939 $>t$ tabel sebesar 1,971 sehingga ditolak dan diterima. Artinya ada pengaruh secara parsial antara Motivasi (X2) dengan Kinerja Organisasi (Y). Sedangkan dilihat dari nilai signifikannya 0,000 lebih kecil dari 0,05 sehingga Ho ditolak dengan demikian dapat disimpulkan bahwa Motivasi (X2) berpengaruh positif secara signifikan terhadap Kinerja Organisasi $(\mathrm{Y})$.

Hasil penelitian ini mendukung penelitian terdahulu yang dilakukan oleh Adam Lubis (2015) "Pengaruh Budaya Organisasi Dan Motivasi Terhadap Kinerja Pegawai Negeri Sipil (Studi Kasus Dinas Perizinan Kota Yogyakarta)" Analisis yang digunakan adalah analisis kuantitatif. Berdasarkan analisis yang telah dilakukan diperoleh hasil bahwa budaya organisasi dan motivasi secara terpisah berpengaruh signifikan terhadap kinerja pegawai negeri sipil.

\section{Pengaruh variabel Budaya Organisasi (X1) dan Motovasi (X2) secara bersama- sama terhadap Kinerja Organisasi (Y)}

Berdasarkan hasil perhitungan, diperoleh angka F penelitian sebesar 256,186 > $\mathrm{F}$ tabel 3,00 dengan tingkat signifikan 0,000 . Karena nilai probabilitas $<0,05$ yaitu $(0,000<$ 0,05) maka ditolak yang artinya variabel Budaya Organisasi (X1), dan variabel Motivasi 
(X2) berpengaruh positif signifikan secara simultan terhadap Kinerja Organisasi (Y).

Hasil penelitian ini mendukung pada penelitian terdahulu yang dilakukan oleh Philip Mustamu (2016), "Pengaruh Gaya Kepemimpinan, Budaya Organisasi, Motivasi, Dan Lingkungan Kerja Terhadap Kinerja Pegawai Di Lingkungan Stasiun BMKG Provinsi Kepulauan Riau".

\section{KESIMPULAN}

1. Berdasarkan hasil perhitungan, iperoleh angka t penelitian sebesar 3,926 > t tabel sebesar 1,971 sehingga ditolak dan diterima. Artinya ada pengaruh secara parsial antara Budaya Organisasi (X1) dengan Kinerja Organisasi (Y). Sedangkan dilihat dari nilai signifikannya 0,000 lebih kecil dari 0,05 sehingga Ho ditolak dengan demikian dapat disimpulkan bahwa Budaya Organisasi (X1) berpengaruh positif secara signifikan terhadap Kinerja Organisasi (Y).

2. Berdasarkan hasil perhitungan, diperoleh angka $t$ penelitian sebesar 10,939 > t tabel sebesar 1,971 sehingga ditolak dan diterima. Artinya ada pengaruh secara parsial antara Motivasi (X2) dengan Kinerja Organisasi (Y). Sedangkan dilihat dari nilai signifikannya 0,00o lebih kecil dari 0,05 sehingga Ho ditolak dengan demikian dapat disimpulkan bahwa Motivasi (X2) berpengaruh positif secara signifikan terhadap Kinerja Organisasi (Y).

3. Berdasarkan hasil perhitungan, diperoleh angka $\mathrm{F}$ penelitian sebesar 256,186 $>\mathrm{F}$ tabel 3,00 dengan tingkat signifikan o,ooo. Karena nilai probabilitas < 0,05 yaitu $(0,000<0,05)$ maka ditolak yang artinya variabel Budaya Organisasi (X1), dan variabel Motivasi (X2) berpengaruh positif signifikan secara simultan terhadap Kinerja Organisasi (Y).

\section{SARAN}


Fourth Edition. McGraw-Hill Education.

Durbin, Andrew J. 2010. Essentials of Management, South-Western Cengage Learning,

Emeka, Nwosu Hyginus., Dr. 2015. Effect of Strategic Planning on Organizational Performance: A Study of Selected Brewing Firms in Nigeria. The International Journal of Bussiness \& Management. Vol. 3, pp 169.

Griffin, Ricky W., Geoffrey Hirt, Linda Ferrell. 2016. Fundamental of Management, Eight Edition. Cengage Learning.

Lestari, Rini. 2013. Pengaruh Manajemen Risiko Terhadap Kinerja Organisasi. Jurnal Riset Akuntansi dan Bisnis. Vol. 13, No.2, pp 140.

Kementerian Komunikasi dan Informatika,. 2009. Panduan Keterbukaan Informasi Publik (KIP) Untuk Petugas Pengelola dan Pemberi Informasi di Badan Publik, Jakarta ; 2009.

Kementerian Komunikasi dan Informatika,. 2015. Pedoman Pengelolaan Informasi dan Dokumentasi Bagi Pejabat Pengelola Informasi dan Dokumentasi Pada Badan Publik Negara Tingkat Pusat dan Daerah. Jakarta ; 2015.

Mahmudi,. 2007. Manajemen Kinerja Sektor Publik, Edisi Revisi, UPP-STIM YKPN, Yogyakarta.

Mahmudah, Enny W,. 2015. Effect ISO 9oo2008 QMS, Total Quality Management and Work Environment and Employess Performance at PT Mount Dreams Indonesia in Gresik.. Surabaya. Universitas Bhayangkara.

Memari, Hamid,. dkk. 2013. The Effect of Positive Organizational Behavior of the Staff on Organizational Performance, Based on the Luthans Model in Public Organizational of Behbahan. Vol. 4

Nawawi, Ismail,. 2013. Budaya Organisasi Kepemimpinan dan Kinerja ; Proses Terbentuk, Tumbuh Kembang, Dinamika, dan Kinerja Organisasi, Prenadamedia Group, Jakarta
O.C. Ferrell . 2016. Business A Changing World, Tenth Edition. McGraw-Hill Education.

Omollo, Pamela Akinyi,. 2015. Effect of Motivation on Employee Performance of Commercial Banks in Kenya : A Case Study of Kenya Commercial Banks in Migori County. Vol. 5. Kenya.

Ratna, Rajnish. et al. 2014. Impact of Learning Organization on Organizational Performance in Consulting Industry. International Journal on Global Business Management and Research. Vol. 2, pp 272-289.

Robbins, Stephen. P., dan Mary Coulter. 2016. Management, Thirteenth Edition. Pearson Education Limited.

Soehardi dan Sherlito C. Sable, (2019). Strategi Pemasaran Bisnis Pariwisata di Kota Davao, Filipina. Jakarta: Jurnal Ilmiah Manajemen Ubhara atau http://jurnal.ubharajaya.ac.id/index.p hp/manajemen-ubhara

Salam, Abdullah, 2013. Pengaruh Budaya Organisasi, Kepemimpinan, dan Motivasi Terhadap Kinerja : Studi Kasus Pada PT PLN (Persero) Area Pelayanan dan Jaringan Yogyakarta. Yogyakarta : STIA Alam Ata 